\title{
EVIDENCE OF NON-SELECTIVE LEXICAL ACCESS IN CHILDREN FROM A PORTUGUESE-ENGLISH BILINGUAL SCHOOL
}

\section{EVIDÊNCIA DE ACESSO LEXICAL NÃO SELETIVO EM CRIANÇAS DE UMA ESCOLA BILÍNGUE PORTUGUÊS-INGLÊS}

\author{
Ana Beatriz Arêas da Luz Fontes ${ }^{1}$ \\ Luciana de Souza Brentano ${ }^{2}$ \\ Pâmela Freitas Pereira Toassi ${ }^{3}$ \\ Catherine C. Sittig ${ }^{4}$ \\ Ingrid Finger ${ }^{5}$
}

\begin{abstract}
The issue of language selectivity regarding lexical access of bilingual adults has been thoroughly reported in the literature. However, studies with bilingual children are still limited, especially in the Brazilian context, where the number of bilingual schools has been increasing rapidly in the last few years To fill this gap, the present study was conducted with the goal of investigating whether the same cognate facilitation effect reported for bilingual adults is also true for bilingual children. To do so, two experiments were carried out. In Experiment 1, 53 Portuguese-speaking (L1) children learning English as a second language (L2) from $3^{\text {rd }}$ and $7^{\text {th }}$ grade completed lexical decision tasks, which included cognates, noncognates and pseudowords, in both Portuguese and English. In Experiment 2, 18 age-matched English monolinguals performed the English version of the lexical decision task. The results of Experiment 1 showed that the cognate effect was evident for both $3^{\text {rd }}$ and $7^{\text {th }}$ graders, when the task was performed in the L2. However, no statistical difference between the two grades was found. When performing the task in the L1, the bilingual groups showed no cognate effect, which suggests that these participants had not reached a level of proficiency in which the L2 can influence L1 processing. The results of Experiment 2 showed no cognate facilitation effect for monolinguals, indicating that the results of the early L2 learners, in the English version of the lexical decision task, were indeed due to the cognate status of the words of the bilingual's two languages. In short, the present results favor the nonselective view of lexical access and the effect of proficiency in the perception of cross language similarity.
\end{abstract}

KEYWORDS: Early Second Language Learning. Lexical Access. Non-Selectivity. Cognate Effect. [istep:

RESUMO: A questão da seletividade da língua no acesso lexical de adultos bilíngues tem sido amplamente relatada na literatura. No entanto, estudos com crianças bilíngues ainda são limitados, principalmente no contexto brasileiro, no qual o número de escolas bilíngues tem aumentado rapidamente nos últimos anos. Para preencher essa lacuna, o presente estudo teve com o objetivo investigar se o mesmo efeito de facilitação cognata relatado no caso de adultos bilíngues também é verdadeiro para crianças bilíngues. Para isso, dois experimentos foram conduzidos. No Experimento 1, um total de 53 crianças falantes nativas de português (L1) aprendendo o inglês como segunda língua (L2), de $3^{\mathrm{a}}$ e $7^{\mathrm{a}}$ série, realizaram uma tarefa de decisão lexical que continha cognatos, não- cognatos e pseudopalavras, tanto em português como em inglês. No Experimento 2, 18 monolíngues falantes de inglês realizaram a tarefa de decisão lexical na versão em inglês. Os resultados do Experimento 1 mostraram que o efeito cognato foi evidente para os dois grupos de bilíngues quando a tarefa foi

\footnotetext{
1 Universidade Federal do Rio Grande do Sul, ana.fontes@ufrgs.br, ORCID: https://orcid.org/0000-0002-80755256.

${ }^{2}$ Universidade Federal do Rio Grande do Sul, lubrentano@gmail.com, ORCID: https://orcid.org/0000-00019808-0691.

3 Universidade Federal do Ceará, pamelatoassi.ufc@gmail.com, ORCID: https://orcid.org/0000-0003-3273639X.

4 The Pennsylvania State University, sittigkatie@gmail.com.

5 Universidade Federal do Rio Grande do Sul/CNPq, ingrid.finger@ufrgs.br, ORCID: https://orcid.org/00000002-9779-8615.
} 
Volume 15 - Número 2 - ago/dez de 2020

realizada na L2-inglês, embora não tenha sido encontrada diferença estatística entre as séries. Ao realizar a tarefa na L1, os grupos bilíngues não apresentaram efeito cognato, o que indica que esses participantes não atingiram um nível de proficiência em que a L2 pode influenciar o processamento da L1. Os resultados do Experimento 2 mostraram que não houve efeito de facilitação cognata para os monolíngues, indicando que os resultados dos aprendizes precoces de L2, na versão em inglês da tarefa de decisão lexical foram, realmente, devido ao status de cognato das palavras das duas línguas dos bilíngues. Em suma, os presentes resultados favorecem a visão não seletiva do acesso lexical e o efeito da proficiência na percepção da similaridade entre línguas.

PALAVRAS-CHAVE: Aprendizagem Precoce de Segunda Língua. Acesso Lexical. Não Seletividade. Efeito Cognato.

\section{Introduction}

The topic of lexical access in bilingualism has been a large area of interest in the study of cognitive psychology and psycholinguistics. Understanding how bilinguals access the lexicon of their two languages gives us insights into issues related to language processing and organization. However, despite the great interest in this theme, there are still many open questions. One of these questions refers to whether bilinguals activate lexical representations from both languages when reading in a single language, or whether they can selectively activate the contextually relevant language. A large body of evidence now suggests that lexical representations from both of a bilingual's languages are non-selectively activated (e.g. DIJKSTRA; TIMMERMANS; SCHRIEFERS, 2000; DIJKSTRA; VAN HELL, 2003; GOLLAN; FORSTER; FROST, 1997; JARED; KROLL, 2001; VAN HEUVEN; DIJKSTRA; GRAINGER, 2001; SCHWARTZ; KROLL; DIAZ, 2007; BOUDELAA, 2018; KIM; KIM, 2018; AREAAS DA LUZ FONTES, 2018; TOASSI; MOTA, 2018; PU et al., 2019). The implication is that, despite a bilingual's intentions to use only one language, both languages are activated in parallel, a finding that may bring about significant implications for contexts of bilingual education.

One source of evidence for non-selectivity comes from studies showing cognate facilitation, in which bilinguals are faster to recognize a cognate such as "piano" in English and Spanish than a control word (VAN HEUVEN; DIJKSTRA; GRAINGER, 1998; GOLLAN; FORSTER; FROST, 1997; KROLL; STEWART, 1994; COP, et al., 2017; LAURO; SCHWARTZ, 2019; ANGELE, B. et al., 2019; VANLANGENDONCK et al., 2020; BARCELOS, L.; AREAAS DA LUZ FONTES, in press; TOASSI; MOTA; TEIXEIRA, 2020). In one of the first studies to show cognate facilitation, Caramazza and Brones (1979) had Spanish-English bilinguals perform a lexical decision task in which they had to decide if strings of letters formed a real word in their second language (L2) or not. Bilinguals were faster to recognize words that were cognates with their first language (L1) (e.g. actor-actor) than matched non-cognates. The similar orthographic and phonological representations of cognates in conjunction with the common meanings they share across languages are suggested to allow bilinguals to process these words more efficiently than noncognates (DIJKSTRA; VAN HEUVEN, 2002).

Most cognate facilitation effects, and thus evidence for language non-selectivity in bilingual lexical access, come from studies with adult bilinguals or adult L2 learners ${ }^{6}$. As children acquire a second language though, the construction of their lexicons is of great interest

\footnotetext{
${ }^{6}$ A distinction seems to be made in the literature between bilinguals and L2 learners. The former often includes individuals who have learned both languages from very early on and use them on a daily basis in a bilingual context. The latter frequently includes individuals who are in the process of learning an L2 and use it in specific contexts only. Although the authors of this study adopt Grosjean's (1998) idea of a bilingualism continuum in which both types of individuals could be considered bilinguals, the distinction is kept to align with the literature.
} 
when considering the implications of having two lexicons. The developmental trajectory of young L2 learners' lexical access processes may differ from that of adult L2 learners because of the concurrent development of the same processes in the L1. Because the children who participated in this study are learning English while still fostering their Portuguese linguistics skills, their process of lexical access may differ from those of adults, who learn an L2 with well established L1 linguistic knowledge in place. If an L1 linguistic system is not yet fully developed, then perhaps the types of cross-language interactions that are observed may differ from those occurring in fully developed L1 systems. A few recent studies have analyzed the performance of young bilinguals and L2 learners in lexical access tasks in order to address such developmental issues using the same methodology commonly used in studies with adults (BRENDERS; VAN HELL; DIJKSTRA,2011; POARCH; VAN HELL, 2012; VON HOLZEN; MANI, 2012; BOSMA et al., 2019; SCHRÖTER; SCHROEDER, 2016; SHENG et al.,2016.

For instance, Brenders, van Hell and Dijkstra (2011) examined word recognition of cognates (i.e. same meaning, similar or same orthography and phonology) and false friends (i.e. different meaning, similar or same orthography and phonology) in Dutch speaking children learning L2 English in a sample of $5^{\text {th }}$, $7^{\text {th }}$, and $9^{\text {th }}$ grade children with varying proficiencies. Participants completed an English lexical decision task (L2), as well as a Dutch lexical decision task (L1). In the English lexical decision task, the children were found to process cognates more quickly and with higher accuracy than control words, thus demonstrating that lexical access for child L2 learners is also nonselective. In the Dutch lexical decision task however, there were no differences between the time or accuracy of cognate processing and control word processing. The results can be interpreted in light of the idea that at lower proficiencies a bilingual's L1 has stronger representations than the L2 in the lexicon of bilinguals. The bilingual's first language can affect processing of the second language's words (specifically cognates); however, unless a bilingual is highly proficient in the L2, bilinguals do not experience cognate facilitation effects when processing cognates in the first (stronger) language. The effects of proficiency are especially important when considering cross-language activation effects in children. The concomitant development of both lexicons (i.e., L1 and L2) allows for interactions between the languages that may differ from that of adults. It is therefore imperative to further investigate the developmental trajectory of bilingual children's lexicons, and the implications that proficiency presents.

Cross-language activation has also been found to affect word production of multilingual children. More specifically, cognate facilitation effects have recently been observed in a picture-naming task with L2 learners, as well as simultaneous bilingual and trilingual children. Poarch and van Hell (2012) had German 5- to 8-year-old L2 English learners, German-English bilinguals and trilinguals with various third languages complete picture-naming tasks in both German and English. The authors expected cognate status, relative language proficiency and age of acquisition of L2 to affect the extent to which the other language is activated during language production. A cognate facilitation effect was observed in both directions (i.e., L1 on L2 and L2 on L1) for the simultaneous bilinguals as well as the trilingual children. The child L2 learners with low proficiencies, on the other hand, only showed cognate facilitation when performing the task in the L2. As in Brender et al.'s (2011), proficiency in the L2 was not strong enough to exert cross-language activation effects on the native language, as were observed in proficient bilingual children, as well as a group of adult bilinguals. The results exemplify the developmental path of language integration that takes place during second language acquisition, while suggesting that lower levels of proficiency in the nonnative language limit cognate facilitation and cross-language activation. These results provide further support for the account of non-selective lexical access and the implications of proficiency on cross-language activation. 
In addition to investigating language nonselective lexical access with bilingual children, latest research has tested it with bilingual toddlers (21-23 months old). Von Holzen and Mani (2012) examined whether words from bilingual toddler's L2 would prime their recognition of words in the L1. In contrast to Brenders et al. (2011) and Poarch and van Hell (2012), this study investigated phonological-level rather than lexical-level cross-language effects on bilingual toddlers' word recognition. To do so, toddlers completed a phonological priming task in which they heard prime-target pairs that were either phonologically related, with L2 primes overlapping phonologically with L1 target words [e.g., slide (L2 prime)-Kleid (L1 target, "dress")] or phonologically related through translation, with L1 translations of L2 primes rhyming with the L1 target words [e.g., leg (L2 prime, 11 translation, "Bein")-Stein (L1 target, "stone")]. The facilitated recognition of targets in the phonological priming condition, along with a late interference effect on target recognition in the phonological priming through translation conditions suggests that both of the toddlers' languages were activated during auditory word recognition. The authors argued that the L2 prime (leg) could only influence L1 target recognition (Stein) if both the L2 prime and its L1 translation ("Bein") were co-activated. Thus, these results provide further evidence of cross-language activation and language nonselective language access in young bilinguals. This is evident even as bilinguals begin to acquire their L2, at as early as 21-23 months of age.

A longitudinal study with 120 West Frisian-English bilinguals (BOSMA et al., 2019) investigated children's sensitivity to different degrees of cross-language similarity in 3 age intervals: from 5 to 6 , from 6 to 7 , and from 7 to 8 . In addition, intensity of exposure to Frisian at home varied among low, middle and high. The experiment consisted of a receptive Frisian vocabulary test in which the items had cross-language similarity manipulated in a way that there were identical cognate words, non-identical cognate words with variable phonological regularity and non-cognate words. The results showed that the degree of semantic and phonological overlap of cognate words interfered with bilingual lexical activation. The greatest the similarity, the easiest the word recognition of the group with low exposure to Frisian. In addition, the children on the third age interval demonstrated a greater sensitivity to a lower degree of similarity, indicating that cross-language similarity interacts with bilingual children's growth and it may also indicate some degree of metalinguistic awareness development. These results add to the ones reported by Brenders et al. (2011) and Poarch and van Hell (2012) in which proficiency played a role in the effect of cross language similarity.

The effect of proficiency on the perception of cross-language similarity was reinforced by the study of Schröter and Schroeder (2016), since the bilingual participants of their study had an equivalent knowledge of their L1 and L2. They were balanced German - English bilinguals recruited from a bilingual school in Berlin, Germany, in which the two languages were used on an equal amount. Participants were $463^{\text {rd }}$ graders who performed a lexical decision task which contained cognates, false friends and control words, both in German and in English. Cognate effects were found in the tasks in the two languages. False friends, on the other hand, had no effect in language processing for both languages. These results favor the cognate facilitation effect and the view that, with a higher proficiency in the L2, this effect can also be seen in L1 processing.

Besides investigating cognate effects in Spanish-English bilinguals' receptive vocabulary as Bosma et al. (2019), Kelley and Kohnert (2012) added an expressive vocabulary test to their study. The 30 bilingual children tested had an age range from 8 to 13 years old. The results of the study showed that the bilingual children were faster in both vocabulary processes, receptive and expressive, when the words were cognates as compared to the noncognate ones. The authors explain that the cognate advantage was greater with items classified as medium or hard in the tests. This means that bilinguals might benefit more from the cognate status of less known words as compared to more known words. 
Evidence in favor of the cognate facilitation effect was also gathered by Sheng et al. (2016), who applied a picture naming task to children aged between 4 and 7 years old. Two bilingual groups participated in the study: one with 34 L1-Spanish- L2 -English and the other with 52 L1-Mandarin - L2- English. In addition, there was a monolingual English control group with 37 participants. The pictures to be named represented cognate and noncognate words in the pair Spanish-English, therefore the bilingual group whose L1 was Mandarin was also a control group. The bilingual groups participated in two experimental sessions, one in which they named pictures in their L1 and the other in English (their L2). The monolingual group was only required to take part in one experimental session. The results showed that only the bilingual Spanish-English group demonstrated differences regarding naming pictures that represented cognate and non-cognate words, which was the expected result, favoring the effect of bilingualism in language production.

Although many studies on bilingual lexical access have focused on adult bilinguals or L2 learners, the research presented here demonstrates that the same effects observed with adults hold for bilingual children and toddlers. Namely, bilingual lexical access seems to be nonselective in nature from very early stages in language acquisition. The present study expands upon these findings by investigating bilingual children who attend a bilingual school in Brazil and comparing their performance to a group of monolingual English-speaking children. Therefore, while the present study builds on the existing literature, it differs from the previous studies by indirectly exploring the role of a bilingual curriculum on processes of word recognition. The two lexical decision experiments carried out to address this issue, the first with a group of Portuguese-English bilinguals and the second with monolingual children, are presented in the following sections.

\section{Experiment 1}

An important aspect of bilinguals' language use is context. The English learners who participated in this study are from a prestige bilingual curriculum at a private school in Brazil. Most of them speak the L2 only at school, where they have 10 hours of lessons in English and 20 hours in Portuguese per week. In this bilingual curriculum some contents are taught in Portuguese, such as Language Arts, Geography, Music and Physical Education and some contents are taught both in English and Brazilian Portuguese, such as Math, Science, Arts, and History. This is in contrast to the average 2 hours per week in English, commonly taught in the Brazilian standard elementary schools. The bilingual curriculum starts in kindergarten, but new incoming children may enter it in later grades as long as they pass a proficiency test. Despite the increased use of English at school, the great majority of these students' families is monolingual and speaks only Portuguese at home. The same is true in the community where the local population speaks only Portuguese. Still, the children who participated in this study reported using English outside of the school setting for activities such as listening to music and playing video games. Therefore, although their contact with English is predominantly via instruction, they also have contact with their L2 outside school.

In summary, these children learn and use the L2 mostly in a school context, compared to the usual sample of bilinguals in the literature who may also use the languages at home and/or in the community. Thus, it is possible to assume that these children who have learned and use the L2 predominantly in the school context do not have as many opportunities to use the language as individuals who live in a bilingual community.

Within this context, the present study examined whether using an L2 mainly in an academic setting had a similar effect on bilingual lexical access as being immersed in a bilingual community. Cross-language activation effects were expected to be present in this sample as evidenced by cognate facilitation effects. Thus, in Experiment 1 we expected bilingual children 
from a school-context to show a cognate facilitation effect, similar to that observed in previous studies (BRENDERS; VAN HELL; DIJKSTRA, 2011; POARCH; VAN HELL, 2012; VON HOLZEN; MANI, 2012; KELLEY; KOHNERT, 2012; SCHRÖTER; SCHROEDER, 2016; SHENG et al., 2016; BOSMA et al., 2019). In addition, we hypothesized that the cognate facilitation effect would be larger as years studying in the bilingual curriculum increased. Finally, we expected a bi-directional cognate facilitation effect (i.e., in both the L2 and L1) only for bilinguals with more years in the bilingual curriculum.

\subsection{Participants}

Participants were 53 Portuguese-speaking children learning English as an L2 enrolled in $3^{\text {rd }}$ and $7^{\text {th }}$ grades of a bilingual curriculum school, located in Novo Hamburgo, a small city in the south of Brazil. They study 30 hours per week (10 hours in English and 20 hours in Portuguese). The group of $3^{\text {rd }}$ graders consisted of 17 boys and 9 girls of about 8 years of age $(M=8.3)$, while the group of $7_{\text {th }}$ graders had 14 boys and 13 girls that were about 13 years old $(\mathrm{M}=12.9)$. The $3^{\text {rd }}$ graders had been studying in the bilingual program for 4 years, whereas the

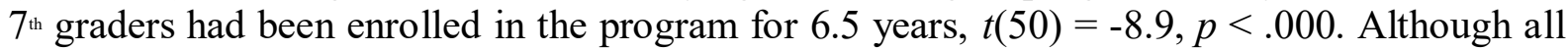
children were currently enrolled in the bilingual program, seven $3^{\text {rd }}$ graders and nine $7^{\text {th }}$ graders had begun studying English before starting at the bilingual program. About $30 \%$ of the children in each group were reported to speak both Portuguese and English at home with parents $(31 \%$ for $3^{\text {rd }}$ graders and $30 \%$ for $7^{\text {th }}$ graders). In addition, parents reported their children to use English outside of the school setting about three times a week for the $3^{\text {rd }}$ graders $[\mathrm{M}=3.7, \mathrm{SD}=2.5$; on a scale from 1 (daily) to 8 (less than twice or three times a year)] and about twice a week for the $7_{\text {th }}$ graders $(M=2.7, S D=2.2)$. This use outside of school included activities such as reading, playing video games, watching television and listening to music in English, but did not differ across groups $(p>.05)$. The children's English language teachers reported on students' English proficiency in reading, writing, speaking and listening comprehension on a scale from 1 to 10, where 1 meant "not proficient at all" and 10 meant "highly proficient". The average proficiency of $7^{\text {th }}$ graders $(\mathrm{M}=7.6, \mathrm{SD}=.95)$ was rated higher than that of $3^{\text {rd }}$ graders $(\mathrm{M}=8.7, \mathrm{SD}=1.10)$, $t(49)=3.3, p<.01$.

\subsection{Task and Materials}

Prior to participating in the study, the children's parents were contacted through the school to obtain consent for their children's participation in the study. At that time, parents also answered a linguistic background questionnaire in which they reported on their child's English use outside of the school environment. The questionnaire included questions about age in which the child began studying English, years spent learning English, daily use of their L2, along with the contexts in which and the people with whom the child used it. There were also questions about traveling and living abroad experiences. These questions were meant to describe the linguistic profile of the participants and were not considered in the analyses of the lexical decision task. The questionnaire, therefore, allowed us to better understand the participants' use of English.

In addition to information about participants' linguistic background, we also needed a measure of their proficiency to verify that it was similar within each grade group. We therefore asked the students' English teacher to rate each participant's proficiency on a scale from 1 to 10 , where 1 meant "not proficient at all" and 10 meant "highly proficient". We asked both teachers, the $3^{\text {rd }}$ and $7^{\text {th }}$ graders', to consider all four abilities (reading, writing, speaking, comprehending) when rating the students. We are aware that such subjective report on students' 
proficiency by their teachers is a limitation of the study, which will be addressed later in the discussion of the results. However, at the time of data collection this was our best option since we believed children, especially the $3^{\text {rd }}$ graders, would not be able to accurately rate themselves, and a standardized test was not within our budget. Still, we needed a measure of the participants' proficiency, so we chose to ask their teachers, who would certainly be able to provide an adequate rating as they follow the children's progress on a daily basis. Because we understand the limitation of our choice we used the teacher-rated proficiency scores only as a variable to describe the participants and not a variable of interest in the analyses. Also, for the same reason and because the standard deviation of teacher-rated proficiency scores within groups was small, no participant was excluded from the sample.

Participants who assented to participation completed a lexical decision task in both English and Portuguese. In the English lexical decision task, children were instructed to press the right button of a response box if the string of letters presented on the computer screen formed a real word in English, and to press the left button if the word did not exist in English. The instructions of the Portuguese task were the same, except that children were asked to recognize if the string of letters formed a real word in Portuguese or not. In both tasks, each trial started with a fixation point, which remained on the screen until participants were ready and pressed the middle key on the response box. A string of letters was presented on the screen immediately after the fixation point and remained on the screen for $5 \mathrm{~s}$ or until participants made a decision. A blank screen followed, which was presented for $1000 \mathrm{~ms}$, and then the next trial began with another fixation point.

To ensure that the younger children would know all the words presented in the task, particularly in the L2 (English), the school provided us with a list of 275 English vocabulary words from the Cambridge Starters Alphabetic Vocabulary List that the $3^{\text {rd }}$ graders had been taught and tested on earlier in the semester (http://www.cambridgeenglish.org/images/84670vocabulary-list.pdf). After excluding all ambiguous words (e.g. plane), false friends (e.g. lunch), and borrowed words (e.g. jeans) we matched a set of 38 cognates (e.g. tomato - tomate) with 38 noncognates (e.g. juice - suco) in frequency (BAAYEN; PIEPENBROCK; GULIKERS, 1995), and number of letters. Thus, the stimulus list used in the English lexical decision task consisted of 76 English words and 76 English-like pseudowords, for a total of 152 test trials. English pseudowords were created by changing one letter of a different set of English words following rules of English word formation. Independent sample $t$-test revealed that there were no differences in frequency or number of letters between the cognates (frequency: $\mathrm{M}=$ $72.49, \mathrm{SD}=98.37$; length: $\mathrm{M}=6.07, \mathrm{SD}=1.83$ ) and noncognates (frequency: $\mathrm{M}=71.97, \mathrm{SD}$ $=97.61$; length: $\mathrm{M}=5.66, \mathrm{SD}=1.51)$. All $p$ values $>.05$.

For the Portuguese lexical decision task, we simply translated the set of 38 cognates and 38 noncognates and created a list of 76 Portuguese-like pseudowords. As with the English pseudowords, Portuguese-like pseudowords were constructed by changing one letter of a new set of Portuguese words following rules of Portuguese word formation. Again, independent sample $t$-tests revealed no difference in frequency or length between the cognates (frequency: $\mathrm{M}=86.89, \mathrm{SD}=159.13$; length: $\mathrm{M}=6.34, \mathrm{SD}=2.06$ ) and noncognates (frequency: $\mathrm{M}=48.70$, $\mathrm{SD}=96.49$; length: $\mathrm{M}=5.71, \mathrm{SD}=1.47)$. All $p$ values $>.05$. Frequencies for the words in Portuguese were obtained using the Corpus Brasileiro database available on www.sketchengine.co.uk (KILGARRIFF et al., 2014).

\subsection{Procedures}

Testing sessions took place at the school site over the course of a week on dates coordinated with the school principal and the bilingual program English language teachers. Only children whose parents had previously signed a consent form participated in the study. 
Participants were taken one at a time from the classroom and brought into an individual testing room where they turned in the language questionnaire previously filled out by their parents at home.

Once in the testing room, participants were seated in front of a laptop computer equipped with a serial response box. Participants were greeted in the language of the task they were to complete first (i.e. English or Portuguese). The order of presentation of the lexical decision tasks was alternated between participants such that some participants completed the English version first, while others completed the Portuguese version first. The task instructions were presented on the computer screen as well as read aloud to the participant by the experimenter. We told participants they would first see a plus sign in the middle of the screen and that they should press the middle button on the response box when they were ready to see the string of letters. We instructed them to press the right button on the response box if the string of letters formed a real word in the language of the task (English or Portuguese), or the left button if the word was not real. They were instructed to make a decision as quickly and accurately as possible as soon as they saw the string of letters on the screen. Participants first completed a set of 20 practice trials to get used to the task. After that, they had a chance to ask questions. Next, participants completed the 152 experimental trials. The same procedure was followed for the lexical decision task in the other language. Instructions were read aloud again in the language of the task. Participants completed 20 practice trials and 152 randomly presented experimental trials. The entire testing session lasted approximately 25 minutes. We thanked children for their participation and took them back to the classroom.

\subsection{Results}

\section{Data trimming}

Reaction time (RT) analysis was performed on the correct responses only. RTs faster than $300 \mathrm{~ms}$, which might indicate that participants were not paying attention to the task, and longer than $3000 \mathrm{~ms}$, which reflects more controlled processing, were considered outliers and excluded from analysis. This led to an exclusion of 14.4\% of trials from the English task and $7.9 \%$ from the Portuguese task. In addition, participants with error rates above 30\% were also excluded from analysis (English $=12$ and Portuguese $=3$ participants).

\subsubsection{English lexical decision task}

To ensure that our manipulation of pseudowords was successful we compared RTs and error rates to words with that of pseudowords. Words in English $(\mathrm{M}=1187.2, \mathrm{SD}=287.5)$ were recognized faster than the English-like pseudowords $(\mathrm{M}=1605.4, \mathrm{SD}=417.5), t(52)=$ $11.8, p<.000$. Similarly, participants made less errors to words $(\mathrm{M}=7.9, \mathrm{SD}=6.2)$ than to pseudowords $(\mathrm{M}=12.8, \mathrm{SD}=9.1), t(40)=2.6, p<.000$.

To test the hypothesis that participants would be faster to recognize cognates than noncognate controls in the L2 (English) with increased years in the bilingual curriculum (measured by grade level) we performed a repeated measures ANOVA with cognate status (cognate or noncognate) as the within subject variable and grade level ( $3^{\text {rd }}$ or $\left.7^{\text {th }}\right)$ as the between subject variable. The RT analysis revealed a main effect of cognate status, $F(1,51)=7.6$, MSE $=10806.2, p<.01$, demonstrating that students from both grades were faster to recognize cognates $(M=1162.6)$ than noncognates $(M=1218.3)$. The interaction between cognate status and grade level was not significant, $p>.05$. The analysis of error rates generated the same pattern of results. There was a main effect of cognates status, $F(1,39)=8.9$, MSE $=39.8, p<$ .01 , demonstrating participants' higher error rates on noncognates $(M=10.4)$ than on cognates 
$(\mathrm{M}=6.2)$. The interaction with grade level was not significant, $p>.05$.

Together, these results demonstrate that cross-language activation effects are present even for children in the beginning stages of L2 learning, who have had exposure to English primarily in formal, educational settings. More interestingly, cognate facilitation effects were observed even with children who had only had about four years of exposure to the L2 at school.

\subsubsection{Portuguese lexical decision task}

In order to verify that our manipulation of pseudowords in Portuguese succeeded we compared RTs and error rates to words with that of pseudowords. Words in Portuguese $(\mathrm{M}=$ 1179.8, $\mathrm{SD}=321.6)$ were recognized faster than the Portuguese-like pseudowords $(\mathrm{M}=1484.9$, $\mathrm{SD}=413.4), t(52)=9.7, p<.000$. Similarly, participants made less errors to words $(\mathrm{M}=5.9$, $\mathrm{SD}=4.4)$ than to pseudowords $(\mathrm{M}=9.3, \mathrm{SD}=7.9), t(49)=2.9, p<.01$.

To test the hypothesis that only learners with more years in the bilingual curriculum, the $7^{\text {th }}$ graders, would show a cognate facilitation effect in the opposite direction (L2 activation during L1 processing), we conducted the same repeated measures ANOVA with RTs and error rates from the lexical decision task in Portuguese. For both RTs and error rates, neither the main effect of cognate status, nor the interaction between cognate status and grade level were significant, all $p$ values $>.05$. These results suggest that participants in both grades recognized noncognates with similar speed and accuracy as cognates. Contrary to our hypothesis, the children with more years in the bilingual curriculum (i.e. $7^{\text {th }}$ graders) did not show activation of the L2 while processing in the L1. Perhaps their proficiency was not yet to the level for such effects to be observed. Indeed, a post-hoc regression analysis revealed that 7 th graders' average English proficiency (across the four skills) did not predict RTs $[\mathrm{R} 2=.118, \mathrm{~F}(1,23)=3.1$, MSE $=46467.6, \mathrm{p}=.093]$ or error rates $[\mathrm{R} 2=.129, \mathrm{~F}(1,23)=3.4, \mathrm{MSE}=37.8, \mathrm{p}=.078]$ associated to the recognition of English words in the lexical decision task. Results from both the English and Portuguese tasks will be discussed further in the discussion section.

\section{Experiment 2}

In Experiment 2 we tested the hypothesis that monolingual children would not show a cognate facilitation effect as they have only one language represented in their mental lexicon. For monolinguals, there is no distinction between noncognates and cognates as the existence of the latter for an individual depends on the knowledge of another language.

\subsection{Participants}

Eighteen $6^{\text {th }}$ graders who spoke English as an L1 and communicated in English only at home and at school participated in the study. The sample consisted of 11 females and 7 males, of ages 11 and $12(\mathrm{M}=11.9, \mathrm{SD}=.58)$. All children attended school at the Quaker Valley School District (QVSD) in Sewickley, PA. The QVSD serves children from medium-high and high income families. Children's self-rated proficiency in English across reading, speaking, writing and speech comprehension was very high $(\mathrm{M}=9.5, \mathrm{SD}=.77)$.

\subsection{Task and Materials}

The same English lexical decision task used in Experiment 1 was used in Experiment 2 as well. 
Volume 15 - Número 2 - ago/dez de 2020

\subsection{Procedures}

Testing sessions took place either at a local library or at the school site. When the testing sessions were held at the local library, parents brought their child to an individual room previously reserved by the experimenters at the library. The child was sat in front of a computer screen and the instructions of the task were explained to him or her. The instructions were the same as in Experiment 1: if you think the string of letters forms a real word in English press the "yes" key on the response box; if you think it does not form a real word press the "no" key on the response box. Upon completion of the computer task children completed the language history questionnaire with the experimenter. The experimenter asked all the questions on the questionnaire and wrote down the answers provided by the children. Finally, children were given an incentive as a token of appreciation for their participation (e.g. a set of pencils, stickers or a puzzle).

If the testing session took place at the school site, the procedure was similar to Experiment 1. Children were taken one by one from their classroom and taken to an individual testing room by the experimenter. The child then sat in front of the computer and was read the instructions to the English lexical decision task. After completing the computer task, the child completed the language history questionnaire with the experimenter and was given an incentive for their participation. The experimenter then took the child back to his or her classroom.

\subsection{Results}

Data trimming procedures

As in Experiment 1, reaction time (RT) analysis was performed on the correct responses only. RTs faster than $300 \mathrm{~ms}$ and longer than $3000 \mathrm{~ms}$ were considered outliers and excluded from analysis. This led to an exclusion of 5.5\% of trials from the English lexical decision task. In addition, participants with error rates above $30 \%$ were also excluded from analysis $(\mathrm{n}=6)$.

To ensure that our manipulation of pseudowords was successful with the monolingual sample we compared RTs and error rates to words with that of pseudowords. Words in English $(\mathrm{M}=985.7, \mathrm{SD}=201.5)$ were recognized faster than the English-like pseudowords $(\mathrm{M}=$ 1356.1, $\mathrm{SD}=293.3), t(45)=-14.3, p<.000$. Similarly, participants made less errors to words $(\mathrm{M}=.03, \mathrm{SD}=.03)$ than to pseudowords $(\mathrm{M}=.08, \mathrm{SD}=.07), t(45)=-4.2, p<.000$.

To test the hypothesis that monolinguals would recognize noncognates just as quickly and accurately as cognates we performed a Paired-sample $t$-test comparing participants' RTs and error rates to cognates and noncognates. Both analyses revealed non-significant results ( $p$ $>$.05) supporting our hypotheses. Contrary to the children early L2 learners from Experiment 1, monolinguals did not demonstrate a cognate facilitation effect, thus supporting additional evidence to non-selective language lexical access during bilingual word recognition.

\section{Discussion}

In the present study we investigated whether the cognate facilitation effect reported in the literature in studies with adults was also true for children who are early L2 learners with a variable degree of exposure to the L2. Two experiments consisting of lexical decision tasks were carried out. In Experiment 1, Portuguese speakers learning English as an L2 from 3rd and $7^{\text {th }}$ grades participated. Experiment 2, on the other hand, was carried out with monolingual English children. 
The results of Experiment 1 showed that the same cognate facilitation effect reported in the literature for adults can be observed in children who use the L2 primarily at school since, for the English lexical decision task, they recognized cognates faster than noncognates. Results also showed that years of schooling in a bilingual curriculum alone does not increase the magnitude of the cognate facilitation effect. Furthermore, the results of Experiment 1 showed that the 3rd graders who had less exposure to English than the 7th graders, as measured by the number of years they were enrolled in the bilingual curriculum at school, also benefited from the cognates in the lexical decision task, demonstrating that this facilitation effect can be observed in the early stages of L2 learning. Although they had less years of schooling in English, the 3rd graders were considered more proficient by their teachers and their parents reported they used more English than the 7th graders outside of school. This may explain the observed cognate facilitation for this group as well as the lack of a difference between the two grades. The 7th graders may be using English at school for a longer period of time, but they seem to use it less frequently outside of school. The varied amount of exposure the participants get from the different contexts may have helped balance out their word recognition performance. Overall, results favored the nonselective hypothesis, which postulates that bilinguals have their two languages activated even when they intend to use only one of these languages (MARIAN; SPIVEY; HIRSCH, 2003; TITONE, et al., 2011).

However, in the Portuguese task there was no effect of cognate status or grade level, indicating that the L2 did not influence L1 processing. This result is consistent with the ones reported by Brenders, van Hell and Dijkstra (2011), Poarch and van Hell (2012), and Bosma et al. (2019) in which the effect of the L2 was not seen in L1 processing. It is possible that the level of L2-English proficiency of the participants in the present study may not have been enough to be reflected on their L1 processing. To address this, we ran a set of post-hoc correlation analyses. An analysis of 7th' graders average English proficiency and their performance on English and Portuguese word trials in the lexical decision task showed no significant correlation, $\mathrm{p}>0.05$. Similarly, 3rd' graders average English proficiency and their performance on English and Portuguese word trials in the lexical decision task revealed a significant correlation only for error rates in the English task, $r=-.628, \mathrm{p}=.001$. This correlation suggests that the greater the teacher-rated proficiency, the less errors 3rd grade students made in recognizing English words. This finding may be interpreted in at least two ways: students' proficiency was not enough to account for performance in the lexical decision task as well as there might be other variables at play that were not addressed in the study. The first possibility is supported by previous research, since a distinct result was reported by Schröter and Schroeder (2016) who tested balanced German bilinguals, instead of early L2 learners such as the children in the present study. This reinforces the assumption that proficiency influences the extent to which bilinguals can rip the benefit of cross language activation. Further investigation may reveal more regarding the extent to which cross-language activation is mediated by L2 proficiency or language use. Our interpretation of the data reported here, however, is that years of studying in a bilingual curriculum along with limited exposure to the L2 outside school is not enough to strengthen L2 lexical representations to the extent that they may impact L1 processing.

In Experiment 2, the results showed no effect of cognate status in the lexical decision of the monolingual English speakers. These results confirm the ones reported for the two groups of early L2 learners in Experiment 1. Therefore, since no cognate effect was observed for the monolingual group in Experiment 2, the results of Experiment 1 can indeed be interpreted as the effect of second language learning, or more precisely, of their emerging bilingualism (Garcia, 2009).

To sum up, not only are the results reported in the present study important because they involved children from a bilingual school context, but also due to their contribution to both 
the literature on bilingual lexical access as well as to the body of psycholinguistic research that aims to help teachers be aware that bilingual children have a unique language repertoire, which can be explored in the classroom. In that sense, for instance, by knowing that the two languages of a bilingual are activated even when they are involved in a monolingual task, we can think of better ways of using the linguistic experience of the student in a favorable way in the classroom, fostering language awareness and development in the two languages simultaneously.

Finally, the study has a few limitations that should be addressed in future research. First, the teacher-rated proficiency scale should be replaced by a more objective and reliable measure of English proficiency, such as standardized tests tailored for children, or perhaps a placement test used by the school. Second, a more comprehensive set of questions about English use outside of school along with more precise frequency estimates should be used. This would allow us to better disentangle proficiency from language use effects on lexical access. Third, we did not account for handedness, so although small, this could have an effect on response times and should be controlled for in the future. Finally, for more robust effects, a larger sample would be necessary.

\section{Conclusion}

Bilingual lexical access has been a prominent topic in cognitive psychology and psycholinguistics. Understanding how the two languages of a bilingual are accessed gives us insights into language processing in general. However, most studies have been conducted with bilingual adults. Therefore, it is important to investigate whether the same results apply for children, mainly in different developmental phases and with different level of L2 knowledge. That was the purpose of the present study, in which two experiments were carried out. One with groups of children of a bilingual school (Portuguese-English), from the $3^{\text {rd }}$ and $7^{\text {th }}$ grade and another with English monolingual children. In Experiment 1, the bilingual children performed one English and one Portuguese version of a lexical decision task containing cognate and noncognate words. In Experiment 2, English monolinguals performed the English version of the lexical decision task.

The results of Experiment 1 showed that both groups of early L2 learners benefited of the cognate facilitation effect, regardless of the number of years in which they were exposed to the L2. On the other hand, in Experiment 2 there was no effect of the cognate words presented in the task. Based on these results, therefore, we can conclude that cognate words are recognized faster by the two groups early L2 learners due to the nonselective lexical access.

The findings reported in the present study make an important contribution to studies in the area, as they highlight a context that is rarely reported in previous studies. In general, it seems that the bilinguals most commonly investigated are always part of a select sample whose linguistic proficiency is equivalent in both languages, or else bilinguals in contexts in which both languages are present at home and/or in the community. Thus, the novel evidence we bring here about the performance of bilingual children who were exposed to the L2 mainly in a bilingual school and whose amount of input in the L2 is limited to a specific context advance the findings in the literature - we corroborate previous research while dealing with emerging bilingual children, whose L2 is still in the process of development and such development takes place mostly at school.

Moving forward it would be interesting to investigate how early bilingual education affects children's brain development. For the group of early L2 learners who participated in the present study the L2 is rarely present in the community and inconsistently in the family context. Although they use English for activities such as listening to music and playing video games, most of the exposure to the language takes place at school. Further investigation may thus show to which extent bilingual education contexts, in which learners are required to manipulate 
Volume 15 - Número 2 - ago/dez de 2020

information and knowledge also in the L2 through activities of coding, decoding, memorizing and evoking that language, together with the need to develop school skills in both languages, may provide children with strengthened brain connections and a possible cognitive reorganization (KROLL; BIALYSTOK, 2013; JASINKÁ et al., 2017).

Finally, these results add to those reported in the literature that favor non-selective bilingual lexical access. Moreover, they provide new data regarding children at different developmental stages and with a limited context of exposure to the L2. We encourage researchers to pursue further investigations in this domain, with different contexts, language combinations and age differences.

\section{References}

ANGELE, B. et al. Trilingual reading: The effect of cognates, false friends, and language proficiency. In: 20th European Conference on Eye Movements, 2019. Alicante, Spain.

AREAAS DA LUZ FONTES, A. B. Acesso lexical bilíngue em tarefas de compreensão leitora. In: ORTIZ-PREUSS, E.; FINGER, I (Orgs.). A dinâmica do processamento bilíngue. Campinas: Pontes, 2018, p.59-82.

BAAYEN, R. H.; PIEPENBROCK, R; GULIKERS L. CELEX2 LDC96L14. Web Download. Philadelphia: Linguistic Data Consortium, 1995.

BARCELOS, L.; AREAAS DA LUZ FONTES, A. B. O acesso lexical de trilíngues brasileiros falantes de português, inglês e francês. In: TAVARES, M. G. G. Tradução, Cognição e Linguística: diálogos e interfaces. no prelo.

BOSMA, E. et al. A longitudinal study on the gradual cognate facilitation effect in bilingual children's Frisian receptive vocabulary. International Journal of Bilingual Education and Bilingualism, v. 22, n.4, p. 371-385, 2019. DOI:10.1080/13670050.2016.1254152.

BOUDELAA, S. Non-selective lexical access in late Arabic-English bilinguals: Evidence from gating. Journal of Psycholinguistic Research, v. 47, n. 4, p. 913-930, 2018. DOI: https://doi.org/10.1007/s10936-018-9564-9.

BRENDERS, P.; VAN HELL, J. G.; DIJKSTRA, T. Word recognition in child second language learners: Evidence from cognates and false friends. Journal of Experimental Child Psychology, v. 109, n. 4, p. 383-396, 2011.

CAMBRIDGE YOUNG LEARNERS ENGLISH TEST - Starters, Movers, Flyers - Handbook for teachers. Cambridge: Cambridge University Press. 2007. Available at: www.CambridgeESOL.org/YoungLearner. Access: 22 jul. 2011.

CARAMAZZA, A.; BRONES, I. Lexical access in bilinguals. Bulletin of the Psychonomic Society, v. 13, n. 4, p. 212-214, 1979.

COP, U. et al. Reading a book in one or two languages? An eye movement study of cognate facilitation in $L 1$ and $L 2$ reading. Bilingualism: Language and Cognition, n.20, v.4, p. 747769, 2017. DOI: https://doi.org/10.1017/S1366728916000213.

DIJKSTRA T.; TIMMERMANS M.; SCHRIEFERS H. On being blinded by your other language: effects of task demands on interlingual homograph recognition. Journal of Memory and Language. v. 42, p. 445-464, 2000. DOI: https://doi.org/10.1006/jmla.1999.2697.

DIJKSTRA, T.; VAN HELL, J. G. Testing the language mode hypothesis using trilinguals. International Journal of Bilingual Education and Bilingualism, v. 6, n. 1, p. 2-16, 2003. DIJKSTRA, T.; VAN HEUVEN, W. The architecture of the bilingual word recognition system: From identification to decision. Bilingualism: Language and Cognition, v.5, p. 175197, 2002.

GARCÍA, O. Bilingual education in the XXI century: a global perspective. Oxford: WileyBlackwell, 2009. 
GOLLAN, T. H.; FORSTER, K. I.; FROST, R. Translation priming with different scripts: Masked priming with cognates and noncognates in Hebrew-English bilinguals. Journal of Experimental Psychology: Learning, Memory, and Cognition, v. 23, n. 5, p. 1122, 1997. JARED, D.; KROLL, J. F. Do bilinguals activate phonological representations in one or both of their languages when naming words?. Journal of memory and language, v. 44, n. 1 , p. 2-31, 2001.

JASINKÁ, K.K. et al. Bilingualism yields language-specific plasticity in left hemisphere's circuitry for learning to read in young children. Neuropsychologia, v. 98, abr, p. 34-45, 2017. Available at: https://www.sciencedirect.com/science/article/pii/S0028393216304195. Access: 22 mar. 2020.

KELLEY, A.; KOHNERT, K. Is There a cognate advantage for typically developing Spanish-speaking English-language learners? Language, Speech, and Hearing Services in Schools, v. 43, p. 191-204, 2012. DOI: 10.1044/0161-1461(2011/10-0022).

KILGARRIFF, A. et al. The Sketch Engine: ten years on. Lexicography, v.1, p. 7-36, 2014.

KIM, J.; KIM, J. H. Implicit translation during second language lexical processing. Journal of Cognitive Science, v. 19, n. 3, p. 357-375, 2018.

KROLL, J. F.; BIALYSTOK, E. Understanding the consequences of bilingualism for language processing and cognition. Journal of cognitive psychology, v. 25, n. 5, p. 497-514, 2013.

KROLL, J. F.; STEWART, E. Category interference in translation and picture naming: Evidence for asymmetric connections between bilingual memory representations. Journal of Memory and Language, v.33, n.2, p.149-174, 1994.

LAURO, J.; SCHWARTZ, A. I. Cognate effects on anaphor processing. Journal of Experimental Psychology: Learning, Memory, and Cognition, v.45, n.3, p. 381-396, 2019. DOI: https://doi.org/10.1037/xlm0000601.

MARIAN, V.; SPIVEY, M.; HIRSCH, J. Shared and separate systems in bilingual language processing: Converging evidence from eyetracking and brain imaging. Brain and language, v. 86, n.1, p. 70-82, 2011.

PINTO, N. B.; ARÊAS DA LUZ FONTES, A. B. O acesso lexical em falantes mulilíngues português-inglês- italiano. Veredas: Revista de Estudos Linguísticos, no prelo.

POARCH, G. J.; VAN HELL, J. G. Cross-language activation in children's speech production: Evidence from second language learners, bilinguals, and trilinguals. Journal of Experimental Child Psychology, v.111, n.3, p. 419-438, 2012.

$\mathrm{PU}, \mathrm{H}$. et al. Testing for nonselective bilingual lexical access using $\mathrm{L} 1$ attrited bilinguals. Brain Sciences, v. 9, n.126, p. 1-25, 2019. DOI: 10.3390/brainsci9060126.

SCHRÖTER, P.; SCHROEDER, S. Orthographic processing in balanced bilingual children: Cross-language evidence from cognates and false friends. Journal of Experimental Child Psychology, v.141, p. 239-246, 2016. DOI: http://dx.doi.org/10.1016/j.jecp.2015.09.005.

SCHWARTZ, A. I.; KROLL, J. F.; DIAZ, M. Reading words in Spanish and English: Mapping orthography to phonology in two languages. Language and Cognitive processes, v. 22, n. 1, p. 106-129, 2007.

SHENG, L. et al. A robust demonstration of the cognate facilitation effect in first-language and second-language naming. Journal of Experimental Child Psychology, v.141, p. 229-238, 2016. DOI: http://dx.doi.org/10.1016/j.jecp.2015.09.007.

TITONE, D. et al. Bilingual lexical access during $L 1$ sentence reading: The effects of L2 knowledge, semantic constraint, and L1-L2 intermixing. Journal of Experimental Psychology: Learning, Memory, and Cognition, v. 37, n.6, p. 1412-1431, 2011.

TOASSI, P. F. P; MOTA, M., B. Semantic priming effects and lexical access in English as 
L3. Gragoatá (UFF), v.23, n.46, p.354 - 373, 2018.

TOASSI, P. F. P; MOTA, M., B; TEIXEIRA, E. N. The effect of cognate words on lexical access of English as a third language. Cadernos de Tradução, v.4, n.esp.2, p. 74-96, 2020.

VAN HEUVEN, W. J. B.; DIJKSTRA, T.; GRAINGER, J. Orthographic neighborhood effects in bilingual word recognition. Journal of memory and language, v. 39, n. 3, p. 458483, 1998.

VAN HEUVEN, W.J.B.; DIJKSTRA, T.; GRAINGER, J; et al. Shared neighborhood effects in masked orthographic priming. Psychonomic Bulletin \& Review v. 8, p. 96-101, 2001. https://doi.org/10.3758/BF03196144.

VANLANGENDONCK, F. et al. Mixing the stimulus list in bilingual lexical decision turns cognate facilitation effects into mirrored inhibition effects. Bilingualism: Language and Cognition, v. 23, n.4, p. 836-844, 2020. DOI: https://doi.org/10.1017/S1366728919000531.

VON HOLZEN, K.; MANI, N. Language nonselective lexical access in bilingual toddlers. Journal of Experimental Child Psychology, v. 113, n. 4, p. 569-586, 2012. 